\title{
Detection of Ureaplasma urealyticum in urine of patients with systemic lupus erythematosus and healthy individuals by culture and polymerase chain reaction
}

\author{
M. RUNGE, S. RYKENA, K. WILDHAGEN*, H. DEICHER* and H. KIRCHHOFF \\ Institut für Mikrobiologie und Tierseuchen, Tierärztliche Hochschule Hannover, and *Abteilung für Klinische \\ Immunologie, Medizinische Hochschule Hannover, Germany
}

\begin{abstract}
A method was developed to detect Ureaplasma urealyticum in urine by the polymerase chain reaction (PCR). A 457-bp fragment of the urease gene of $U$. urealyticum was amplified by PCR. Before PCR, components disturbing the amplification had to be reduced. This was possible by diluting the urine 1 in 10 with distilled water and by the extraction of the $U$. urealyticum DNA. Urine specimens from 41 patients with systemic lupus erythematosus (SLE) and 21 healthy individuals were treated by the dilution method and investigated by PCR for $U$. urealyticum DNA. The results were compared with those obtained by culture and the detection rates of PCR and culture were found to be identical. Also there was no difference in the detection rates of $U$. urealyticum from urine of SLE patients and healthy individuals; $10(24.4 \%)$ of the 41 urine specimens from SLE patients and five (23.8\%) of the 21 urine specimens from healthy individuals gave positive results for $U$. urealyticum. The results of this study do not indicate a decisive role for $U$. urealyticum in SLE.
\end{abstract}

\section{Introduction}

Ureaplasma urealyticum was described by Shepard et al. [1] who isolated it in 1954 from the genitourinary tract of men with non-gonococcal urethritis. It belongs to the family Mycoplasmataceae and differs from Mycoplasma species by its ability to hydrolyse urea. Robertson and Stemke [2] identified 14 serotypes of $U$. urealyticum. These serotypes can be divided into two biotypes based on protein patterns obtained by gel electrophoresis, percentage DNA-DNA hybridisation, restriction fragment length polymorphism, sensitivity to $\mathrm{Mn}^{2+}$ and enzyme profiles [3].

U. urealyticum has been associated with several diseases, such as urethritis, prostatitis, vaginitis, infertility, certain complications during pregnancy and pneumonia in neonates [4-7]. In a study of patients suffering from systemic lupus erthyematosus (SLE), a multisystemic autoimmune disease of unknown aetiology, Ginsburg et al. [8] suggested a link between SLE and chronic colonisation of the female genitourinary tract with $U$. urealyticum.

Received 4 June 1996; revised version accepted 14 Oct. 1996.

Corresponding author: Dr M. Runge.
The aim of the present study was to develop a method for the detection of $U$. urealyticum by polymerase chain reaction (PCR) and to perform further investigations about the possible role of $U$. urealyticum in SLE.

\section{Materials and methods}

Specimens

Early stream urine samples were taken from 41 female patients with SLE and 21 healthy individuals (17 female, four male). These urine specimens were examined for $U$. urealyticum by culture and PCR. All patients satisfied at least four American College of Rheumatology (formerly, American Rheumatism Association) criteria for SLE [9]. The mean duration of the disease was 96 months. The mean age of the patients was 44 years (range 16-60 years). The mean age of the healthy individuals was 33 years (range 22-64 years).

\section{Micro-organisms and media}

The following strains representing the 14 serotypes of $U$. urealyticum (kindly provided by Dr J. Robertson, University of Alberta, Canada) were used as controls for the sensitivity and specificity of the PCR: strain 7 (serotype 1), strain 23 (serotype 2), strain 27 (serotype 
3), strain 58 (serotype 4), strain 354 (NIH; serotype 5), strain Pi (serotype 6), strain Co (serotype 7), strain T960 (CX 8) (serotype 8), strain Vancouver (serotype 9), strain Western (serotype 10), strain K2 (serotype 11), strain U24 (serotype 12), strain U38 (serotype 13) and strain U26 (serotype 14).

U. urealyticum strains were cultivated in bromothymol blue broth according to Robertson [10] and in ureaplasma differential basal (A7) agar medium according to Shepard and Lunceford [11]. These media were also used for the cultural investigation of the urine specimens from the SLE patients and healthy individuals. PPLO broth (Difco Laboratories Detroit, Michigan, USA) containing PPLO serum fraction (Difco) $1 \% \mathrm{v} / \mathrm{v}$ and penicillin (Hoechst, Frankfurt, Germany) 100000 IU was used as transport medium.

Mycoplasma bovis PG45 - a member of the family Mycoplasmataceae - and Proteus vulgaris (field strain; Institut für Mikrobiologie und Tierseuchen, Tierärztliche Hochschule, Hannover, Germany), a micro-organism with an urease gene, served as negative controls in the PCR.

\section{Culture method}

One $\mathrm{ml}$ of the urine sample was diluted immediately upon receipt with $2 \mathrm{ml}$ transport medium. The remaining urine was kept in a separate vial. In the laboratory, $0.2 \mathrm{ml}$ each of the diluted and undiluted urine were transferred to $1.8 \mathrm{ml}$ of bromothymol blue broth and $10 \mu 1$ of each were plated on to A7 agar medium. A further $1 \mathrm{ml}$ of the diluted and $1 \mathrm{ml}$ of the undiluted urine samples were centrifuged for $10 \mathrm{~min}$ at $14000 \mathrm{~g}$ at $4^{\circ} \mathrm{C}$. A portion $(700 \mu \mathrm{l})$ of each supernate was decanted and the sediments were resuspended in the remaining $300 \mu \mathrm{l}$. From these suspensions, $0.2 \mathrm{ml}$ were transferred to $1.8 \mathrm{ml}$ of bromothymol blue broth and $10 \mu \mathrm{l}$ were plated on to $\mathrm{A} 7$ agar medium. Liquid media were incubated in an atmosphere of $\mathrm{CO}_{2} 5 \%$ at $37^{\circ} \mathrm{C}$ and examined twice daily for colour change without turbidity. Immediately after colour change, $0.1 \mathrm{ml}$ was plated on to A7 agar. Agar media were incubated in an anaerobic atmosphere (Gas generating kit for anaerobic bacteria; Oxoid, Wesel, Germany) at $37^{\circ} \mathrm{C}$ and examined after incubation for $48 \mathrm{~h}$ and then daily for the characteristic small dark brown colonies. Urine samples were considered as positive by culture only after the detection of ureaplasma colonies, as colour change of the liquid medium, not combined with turbidity - occasionally used as an indication for growth of ureaplasma - can also originate from a small number of other urease-producing micro-organisms.

\section{Determination of the number of colony-forming units (cfu)}

The numbers of cfu were determined according to the method of Albers and Fletcher [12] with slight modifications. Four-fold dilutions of the broth cultures of $U$. urealyticum were produced by charging the wells of sterile microtitration plates with $150 \mu \mathrm{l}$ of bromothymol blue broth and serially transferring $50 \mu 1$ volumes. By this procedure dilutions of 1 in 4,1 in 16 up to 1 in 65536 were obtained. Ten $\mu 1$ of each dilution were plated on to A7 agar immediately after production and incubated for 6 days as indicated above. Dilutions yielding 10-100 colonies of $U$. urealyticum were counted. The number of $\mathrm{cfu} / \mathrm{ml}$ of the original Ureaplasma culture was determined as a mean of three investigations according to the formula: $\mathrm{cfu} / \mathrm{ml}=$ cfu $\times 100 \times$ dilution.

\section{Development of a protocol for the detection of $U$. urealyticum in urine by $P C R$}

Urine samples of healthy individuals which were culture negative for $U$. urealyticum were inoculated with different numbers of cfu of $U$. urealyticum. These samples were used for the development of a method suitable for the detection of $U$. urealyticum in urine by PCR. To reduce the amount of the components disturbing PCR, two approaches were tried before PCR: dilution of the urine specimens, and extraction of the ureaplasma DNA.

Dilution of urine specimens. The urine specimens were diluted with distilled water before PCR. Dilutions containing $10-90 \%$ urine and undiluted urine were used as templates in the PCR.

DNA extraction. Two methods were used for the extraction of the ureaplasma DNA. The first was a modification of the method described by Schleif and Wensingk [13]: $100 \mu \mathrm{l}$ of liquid culture containing $10^{5}$ cfu of $U$. urealyticum were mixed with $900 \mu 1$ urine and subjected to microwave irradiation (Philips, Space Cube 50) for $20-30 \mathrm{~s}$ at $650 \mathrm{~W}$. After centrifugation at $12000 \mathrm{~g}$ and $4^{\circ} \mathrm{C}$ for $30 \mathrm{~min}$, the supernate was removed and mixed with $50 \mu \mathrm{l}$ of a reaction buffer containing $0.1 \mathrm{M}$ Tris, $\mathrm{pH} 7.8,0.05 \mathrm{M}$ EDTA, SDS 5\% $\mathrm{w} / \mathrm{v}$ and proteinase $\mathrm{K}$ (Boehringer, Mannheim, Germany) $500 \mu \mathrm{g}$ and then incubated for $1 \mathrm{~h}$ at $56^{\circ} \mathrm{C}$. After centrifugation at $12000 \mathrm{~g}$ and $4^{\circ} \mathrm{C}$ for $15 \mathrm{~min}$ the DNA was separated by adding an equal volume of phenol:chloroform:isoamyl alcohol $(25: 24: 1)$ to the supernate and shaking for $15 \mathrm{~min}$ at room temperature. After centrifugation for $10 \mathrm{~min}$ at $3000 \mathrm{~g}$ the DNA was precipitated from the aqueous phase with 2 volumes of absolute ethanol containing glycogen $1 \mu \mathrm{l}$ and $3 \mathrm{M}$ sodium acetate, $\mathrm{pH} 5.2,40 \mu \mathrm{l}$ and incubated overnight at $-20^{\circ} \mathrm{C}$. After centrifugation for $30 \mathrm{~min}$ at $12000 \mathrm{~g}$ and $0^{\circ} \mathrm{C}$, the ethanol was decanted and the DNA was dried and resuspended in $10 \mu \mathrm{l}$ of distilled water. This solution was used for PCR. In the second method DNA was extracted by the Qiaex gel extraction kit (Diagen, Hilden, Germany). The extraction procedure was performed according to the manufacturer's instructions. Briefly, a suspension of 
urine $90 \mu \mathrm{l}$ and liquid culture of $U$. urealyticum $10 \mu \mathrm{l}$ containing $10^{4} \mathrm{cfu}$ was added to a mixture of $\mathrm{QX} 1$ buffer $\left(3 \mathrm{M} \mathrm{NaI}, 4 \mathrm{M} \mathrm{NaClO}_{4}, 10 \mathrm{~mm}\right.$ Tris-HCl, pH $\left.7.0,10 \mathrm{mM} \mathrm{Na} \mathrm{S}_{2} \mathrm{O}_{3}\right) 300 \mu \mathrm{l}$ and Qiaex silica gel $10 \mu \mathrm{l}$. After incubation for $10 \mathrm{~min}$ at $50^{\circ} \mathrm{C}$ the mixture was centrifuged for $30 \mathrm{~s}$ at $12000 \mathrm{~g}$. The pellet was resuspended in $500 \mu \mathrm{l}$ of QX2 buffer $\left(8 \mathrm{M} \mathrm{NaClO}_{4}\right.$, $10 \mathrm{mM}$ Tris- $\mathrm{HCl}, \mathrm{pH} \mathrm{7.0)}$ and again centrifuged. After repeating this step the pellet was resuspended in QX3 buffer (ethanol $70 \% \mathrm{v} / \mathrm{v}, 100 \mathrm{mM} \mathrm{NaCl}, 10 \mathrm{mM}$ Tris$\mathrm{HCl}, \mathrm{pH}$ 7.5) and centrifuged again. Following air drying, the pellet was resuspended in $10 \mu \mathrm{l}$ of $\mathrm{TE}$ buffer, incubated for $5 \mathrm{~min}$ at $50^{\circ} \mathrm{C}$ and centrifuged. The supernate was used for amplification.

\section{PCR}

The two oligonucleotides Uul (5'-GATGGTAAGTTAGTTGCTGAC-3') and Uu2 (5'-ACGACGTCCATAAGCAACT-3'), published by Blanchard [14], flanking a 457-bp fragment of the urease gene of $U$. urealyticum, were used as primers. The PCR was performed on an automated DNA thermal cycler (Perkin Elmer Cetus, Überlingen, Germany) with TaqDNA-polymerase (Stratagene, Heidelberg, Germany). The following served as templates: (i) broth cultures of $U$. urealyticum; (ii) undiluted urine and diluted urine (containing 10-90\% urine) inoculated with different numbers of $\mathrm{cfu}$ of $U$. urealyticum; and (iii) $U$. urealyticum DNA extracted from urine experimentally infected with $U$. urealyticum. M. bovis and $P$. vulgaris were used as negative controls. Amplification was done in a reaction mixture containing $10 \mu \mathrm{l}$ of the sample to be analysed, $10 \mathrm{mM}$ Tris-HCl, $\mathrm{pH} 8.8 ; 50 \mathrm{mM} \mathrm{KCl}$, gelatine $0.01 \%, 1.5 \mathrm{mM} \mathrm{MgCl} 2125 \mu \mathrm{M}$ each of dATP, dCTP, dTTP and dGTP, 10 pmol of each primer and $2.5 \mathrm{U}$ of $T a q$-polymerase per $50 \mu \mathrm{l}$. Samples were denatured at $92^{\circ} \mathrm{C}$ for $1 \mathrm{~min}$. Primers were annealed at $60^{\circ} \mathrm{C}$ for $90 \mathrm{~s}$ and extended at $72^{\circ} \mathrm{C}$ for $2 \mathrm{~min}$. A total of 50 cycles was performed.

\section{Analysis of amplification products}

PCR amplification products were analysed on a vertical polyacrylamide $8 \%$ gel by applying $10 \mu \mathrm{l}$ of product mixed with $2 \mu \mathrm{l}$ of sample buffer containing bromophenol blue $4 \mathrm{mg}, 0.5 \mathrm{M}$ EDTA, $100 \mu \mathrm{l} \mathrm{pH} 8.0$, glycerol $565 \mu \mathrm{l}$ and TBE-buffer (consisting of Tris $5.4 \mathrm{~g}$, borate $2.75 \mathrm{~g}, 0.5 \mathrm{M}$ EDTA $1.0 \mathrm{ml}$, pH 8.0 , in $100 \mathrm{ml}$ of distilled water) $400 \mu \mathrm{l}$. TBE-buffer diluted 1 in 5 with distilled water was used as running buffer. Gel electrophoresis was carried out for $45 \mathrm{~min}$ at $15 \mathrm{~W}$. Bands were visualised by UV fluorescence after soaking the gel for $30 \mathrm{~min}$ in a solution containing ethidium bromide $0.01 \mu \mathrm{g}$, glycerol $2 \mathrm{ml}$ and $400 \mathrm{ml}$ of the diluted TBE-buffer or by silver staining according to Blum et al. [15]. To ensure the specificity, amplification products showing the 457-bp fragment were cleaved with MboI (20 U/20 $\mu \mathrm{l}$; Pharmacia, Freiburg, Germany) for $3 \mathrm{~h}$ at $37^{\circ} \mathrm{C}$ in a solution containing Tris-buffer ( $6 \mathrm{mM}$ Tris- $\mathrm{HCl}, 50 \mathrm{mM} \mathrm{NaCl}$, $6 \mathrm{mM} \mathrm{MgCl}_{2}$ ) $5 \mu \mathrm{l}$ and distilled water $23 \mu \mathrm{l}$. After terminating the reaction by applying $4 \mu \mathrm{l}$ of sample buffer the sample was subjected to gel electrophoresis. A 1-kb DNA ladder (Gibco BRL, Eggenstein, Germany) was used as molecular size marker.

\section{Protocol used for the detection of $U$. urealyticum} in urine of SLE patients and healthy individuals

Urine specimens were investigated by the culture method as indicated above. The PCR used for the clinical evaluation was performed on (i) urine specimens from SLE patients and healthy individuals diluted 1 in 10 with distilled water and (ii) on urine specimens from SLE patients and healthy individuals pre-incubated in liquid medium $(0.2 \mathrm{ml}$ of urine in $1.8 \mathrm{ml}$ of bromothymol blue broth). Amplification was performed as indicated above. The amplification products were visualised by silver staining according to Blum et al. [15].

\section{Results}

Suitability of the methods investigated for the detection of $U$. urealyticum in urine artificially inoculated with $U$. urealyticum by PCR

The detection of $U$. urealyticum in urine by PCR depended on the preparation of the urine for PCR. While detection was impossible with untreated urine, it was successful with diluted urine as well as with the extracted $U$. urealyticum DNA.

With the dilution method the best results were obtained with a 1 in 10 dilution of the urine $(10 \%$ urine). Amplification did not occur in samples containing $>40 \%$ urine and occurred only sporadically in samples containing $20-30 \%$ urine. After 1 in 10 dilution of the urine, $1 \mathrm{cfu}$ of $U$. urealyticum corresponding to $10^{3} \mathrm{cfu}$ of $U$. urealyticum $/ \mathrm{ml}$ of urine - could be detected in the 10- $\mu 1$ sample used as a template in the reaction mixture (Fig. 1).

The detection limit of the PCR performed on DNA of $U$. urealyticum extracted by the Qiaex kit corresponded to $10^{2} \mathrm{cfu}$ of $U$. urealyticum in the $10-\mu 1$ sample, i.e., to $10^{5} \mathrm{cfu}$ of $U$. urealyticum $/ \mathrm{ml}$ of urine. Fragments of $U$. urealyticum DNA extracted by the method according to Schleif and Wensingk [13] could not be amplified in the PCR performed.

The 457-bp fragment of the $U$. urealyticum urease gene amplified by PCR could be cleaved with Mbo I into four fragments of 53, 98, 139 and $166 \mathrm{bp}$, corresponding to the sizes stated (Fig. 2) [14]. DNA from all serotypes of $U$. urealyticum but not from $M$. bovis or $P$. vulgaris was amplified. 


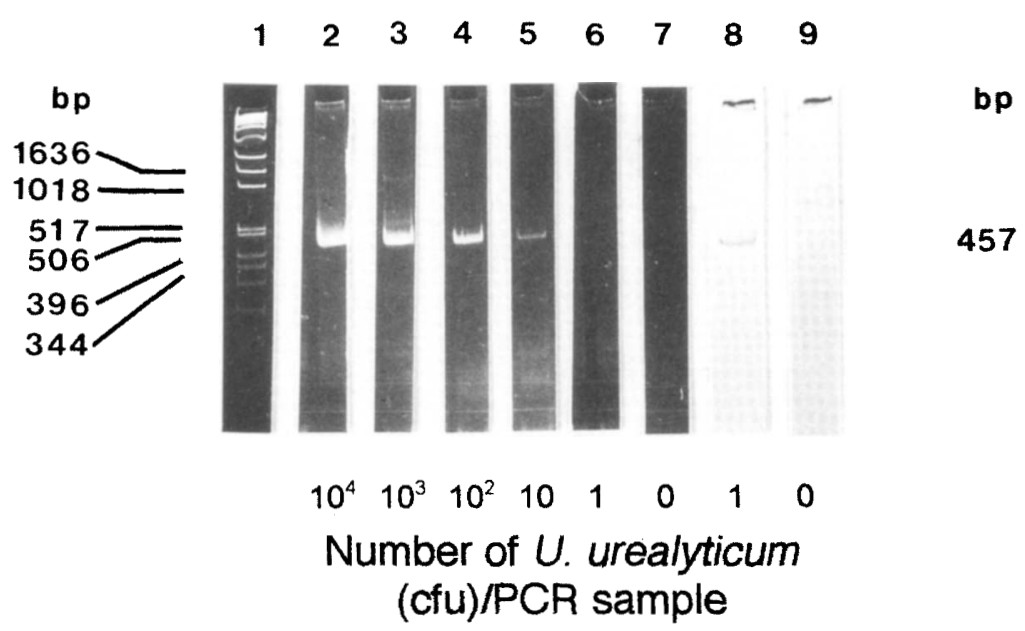

Fig. 1. Detection limit of $U$. urealyticum in samples containing $10 \%$ urine by PCR. Lane 1, molecular size standard; $2-$ $\mathbf{6 , 8}, \mathrm{U}$. urealyticum-free urine samples, diluted 1 in 10 with distilled water and inoculated with $10^{4}(\mathbf{2}), 10^{3}(\mathbf{3}) 10^{2}$ (4), $10(5)$, and $1(6,8)$ cfu of $U$. urealyticum; 7,9 , U. urealyticum-free controls. Samples were separated on a polyacrylamide gel and stained with ethidium bromide (lanes 1-7) or silver (lanes 8 and 9). A 457-bp fragment could be seen after staining with ethidium bromide in samples inoculated with $10^{4}-10 \mathrm{cfu}$ of $U$. urealyticum (lane 5) and after silver staining in samples containing $1 \mathrm{cfu}$ of $U$. urealyticum (8). An amplification product could not be observed by ethidium bromide (lane 7 ) or by silver staining $(9)$ in the negative controls.

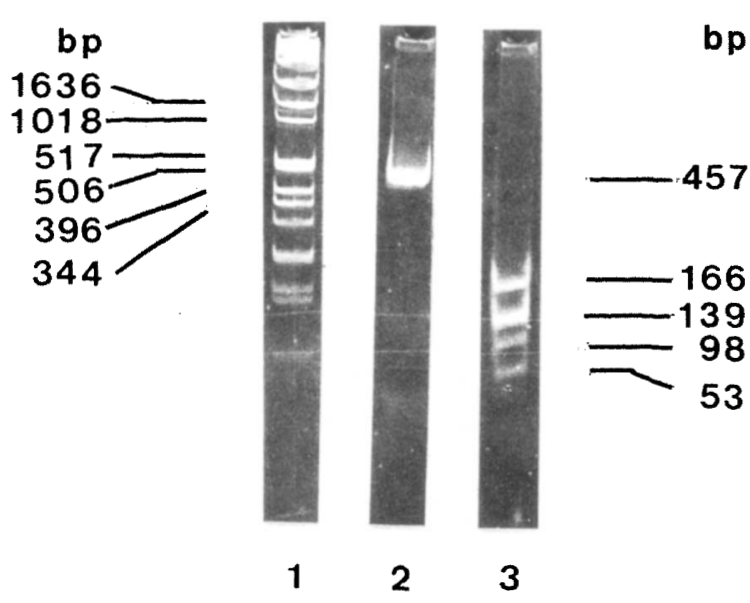

Fig. 2. Characterisation of the 457-bp DNA fragment of the urease gene of $U$. urealyticum amplified by PCR. Lane 1, molecular size standard; 2, 457-bp amplification product of $U$. urealyticum; 3, 457-bp fragment cleaved with $\mathrm{Mbo}$ I into four fragments. Samples were electrophoresed on a polyacrylamide gel and stained by ethidium bromide.

\section{Clinical results}

$U$. urealyticum could be cultivated from the urine of eight $(19.5 \%)$ of the 41 SLE patients investigated and from the urine of four $(19.0 \%)$ of the 21 control individuals (Table 1); $10^{3}-10^{5} \mathrm{cfu}$ U. urealyticum $/ \mathrm{ml}$ urine were isolated from SLE patients and $10^{2}-10^{4} \mathrm{cfu}$ of $U$. urealyticum $/ \mathrm{ml}$ of urine from healthy individuals.

PCR was performed on urine from the SLE patients and the healthy individuals diluted 1 in 10 with distilled water and on urine pre-incubated in bromothymol blue broth. Without pre-incubation, U. urealyticum could be detected in urine specimens of seven (17.1\%) of the 41 SLE patients investigated and in three $(14.3 \%)$ urine specimens of the 21 healthy individuals. After enrichment in bromothymol blue broth, $U$. urealyticum was demonstrated in two more urine specimens, one from an SLE patient and one from a healthy individual (Table 1).

SLE patients revealed eight (19.5\%) urine specimens

Table 1. Detection of $U$. urealyticum in urine samples from patients with SLE and from healthy individuals by culture and PCR

\begin{tabular}{lccccc}
\hline & \multicolumn{4}{c}{ Number of individuals positive for $U$. urealyticum detected by } \\
\cline { 2 - 6 } Source & Culture and $\mathrm{PCR}^{*}$ & Culture only & $\begin{array}{c}\mathrm{PCR}^{*} \text { only without } \\
\text { pre-incubation }\end{array}$ & $\begin{array}{c}\text { PCR } \\
\text { pre-incubation }\end{array}$ & Total $(\%)$ \\
\hline $\begin{array}{l}\text { SLE patients } \\
(\mathrm{n}=41)\end{array}$ & 6 & 2 & 1 & 1 & $10(24.4)$ \\
$\begin{array}{l}\text { Healthy individuals } \\
(\mathrm{n}=21)\end{array}$ & 3 & 1 & 0 & 1 & $5(23.8)$ \\
\hline
\end{tabular}

${ }^{*}$ Amplification products were visualised by silver staining 
positive for $U$. urealyticum by culture and eight $(19.5 \%)$ urine specimens positive for $U$. urealyticum by PCR. In healthy individuals four $(19.0 \%)$ urine specimens were positive for $U$. urealyticum by culture and four $(19.0 \%)$ by PCR; i.e., identical numbers of $U$. urealyticum-positive urine specimens were detected by culture and by PCR. However, it has to be considered that three urine specimens (two from SLE patients and one from a healthy individual) were $U$. urealyticum positive only by culture and three urine specimens (two from SLE patients and one from a healthy individual) only by PCR. In total, U. urealyticum was demonstrated in urine specimens of 10 $(24.4 \%)$ of the 41 SLE patients investigated and in five $(23.8 \%)$ urine samples of the 21 healthy individuals (Table 1).

\section{Discussion}

In the present investigation, a method was developed to detect $U$. urealyticum in urine by PCR and was compared with culture for sensitivity. This method has been used to detect $U$. urealyticum in urine of SLE patients and of healthy individuals.

As $U$. urealyticum could not be detected by PCR in untreated urine specimens inoculated with $U$. urealyticum - probably because of PCR-inhibiting substances - a method had to be developed to reduce the concentration of these components. Two different approaches were pursued: firstly, dilution of the urine and secondly, extraction of the $U$. urealyticum DNA; both approaches appeared to be suitable. However, of the two DNA extracting methods investigated, only the extraction by the Qiaex kit was successful, whereas the method of Schleif and Wensingk [13] did not yield positive results. This may have been due to the high concentration of salts accumulating in the DNAcontaining aqueous phase. As the dilution method was more sensitive (detection limit $10^{3} \mathrm{cfu} / \mathrm{ml}$ of urine), and also much simpler and cheaper than the extraction of DNA (detection limit $10^{5} \mathrm{cfu} / \mathrm{ml}$ of urine), it was applied to the detection of $U$. urealyticum in the urine specimens of patients with SLE and healthy individuals by PCR.

With regard to sensitivity, no difference was observed between the culture method and the PCR. However, since in about one-third of the urine specimens $U$. urealyticum could be detected only by culture, and in one-third only by PCR, the detection rate was increased considerably by using both methods.

The detection rates of $U$. urealyticum in urine of patients with SLE and healthy individuals were almost identical. These results are in contradiction to the results reported by Ginsburg et al. [8] who found a significant difference in the isolation rate of $U$. urealyticum from patients with SLE $(63 \%)$ and control individuals $(4.5 \%)$ for which they used patients with chronic fatigue syndrome. The age and the sociodemographic factors of both groups were the same. However, it is questionable as to whether patients with chronic fatigue syndrome are suitable control individuals. It is well known that the colonisation of the genitourinary tract with $U$. urealyticum depends not only on age and sociodemographic factors, but also on sexual activity $[4,16,17]$. The low colonisation rate of the patients with chronic fatigue syndrome could also be the consequence of a lower level of sexual activity by these individuals.

According to the present investigations, which were performed on SLE patients and healthy control individuals of about the same age, $U$. urealyticum does not play a decisive role in SLE. However, since mycoplasmas are apparently involved in several chronic inflammatory disorders [18-25], further investigations not restricted to the detection in urine may be necessary to definitely rule out any relationship between infection with ureaplasmas and SLE.

Nevertheless, the detection of $U$. urealyticum remains important and necessary because of its involvement in several urogenital diseases. As the cultivation of $U$. urealyticum is laborious, time consuming, and requires specific expertise, the PCR may be a suitable alternative for the detection of $U$. urealyticum in urine.

\section{References}

1. Shepard MC, Lunceford CD, Ford DK et al. Ureaplasma urealyticum gen. nov., sp. nov.: proposed nomenclature for the human T (T-strain) mycoplasmas. Int J Syst Bacteriol 1974; 24 : $160-171$

2. Robertson JA, Stemke GW. Expanded serotyping scheme for Ureaplasma urealyticum strains isolated from humans. $J$ Clin Microbiol 1982; 15: 873-878.

3. Robertson JA, Vekris A, Bebear C, Stemke GW. Polymerase chain reaction using $16 \mathrm{~S}$ rRNA gene sequences distinguishes the two biovars of Ureaplasma urealyticum. J Clin Microbiol 1993; 31: $824-830$.

4. McCormack WM. Ureaplasma urealyticum: ecologic niche and epidemiologic considerations. Pediatr Infect Dis 1986; 5 Suppl 6: $\mathrm{S} 232-\mathrm{S} 233$

5. Harrison HR. Cervical colonization with Ureaplasma urealyticum pregnancy outcome: prospective studies. Pediatr Infect Dis 1986; 5: 266-269.

6. Horowitz S. Ureaplasma colonization of amniotic fluid in early mid-trimester and in premature rupture of membranes. IOM Let 1992; $2: 83$.

7. Robertson JA, Honore LH, Stemke GW, Jenkins HJ. The association of the parvo biotype of Ureaplasma urealyticum with cases of reproductive failure. IOM Lett 1992; 2: 63.

8. Ginsburg KS, Kundsin RB, Walter CW, Schur PH. Ureaplasma urealyticum and Mycoplasma hominis in women with systemic lupus erythematosus. Arthritis Rheum 1992; 35: 429-433.

9. Tan EM, Cohen AS, Fies JF et al. The 1982 revised criteria for the classification of systemic lupus erythematosus. Arthritis Rheum 1982; 25: 1271-1277.

10. Robertson JA. Bromothymol blue broth: improved medium for detection of Ureaplasma urealyticum (T-strain mycoplasma) $J$ Clin Microbiol 1978; 7: 127-132.

11. Shepard MC, Lunceford CD. Differential agar medium (A7) for identification of Ureaplasma urealyticum (human $\mathrm{T}$ mycoplasmas) in primary cultures of clinical material. J Clin Microbiol 1976: 3: $613-625$. 
12. Albers AC, Fletcher RD. Simple method for quantitation of viable mycoplasmas. Appl Environ Microbiol 1982; 43: 958-960.

13. Schleif RF, Wensingk PC. Practical methods in molecular biology. New York, Springer. 1981: 98-99.

14. Blanchard A. Ureaplasma urealyticum urease genes; use of a UGA tryptophan codon. Mol Microbiol 1990; 4: 669-676.

15. Blum H, Beier H, Gross HJ. Improved silver staining of plant proteins, RNA and DNA in polyacrylamide gels. Electrophoresis 1987; 8: 93-99.

16. Taylor-Robinson D. The male reservoir of Ureaplasma urealyticum. Pediatr Infect Dis 1986; 5 Suppl 6: S234-S235.

17. Cassell GH, Waites KB, Watson HL, Crouse DT, Harasawa RR. Ureaplasma urealyticum intrauterine infection; role in prematurity and disease in newborns. Clin Microbiol Rev 1993; 6: 69-87.

18. Taylor-Robinson D, Thomas BJ, Furr PM, Keat AC. The association of Mycoplasma hominis with arthritis. Sex Transm Dis 1983; 10 Suppl 4: 341-344.

19. Taylor-Robinson D, Furr PM, Webster ADB. Ureaplasma urealyticum in immunocompromised host. Pediatr Infect Dis 1986; 5 Suppl 6: S236-S238.
20. Lo S-C, Tsai S, Benish JR, Shih JW-K, Wear DJ, Wong DM, Enhancement of HIV-1 cytocidal effects in CD4+ lymphocytes by the AIDS-associated mycoplasma. Science 1991; 251: 1074-1076.

21. Davis JW, Espinosa D, Williams K, Kissel V. Cabello FC Ureaplasma proteins react with a monoclonal antibody produced against an HLA-B27 antigen. IOM Lett 1990; 1283.

22. Kirchhoff H, Binder A, Runge N, Meier B, Jacobs R, Busche K Pathogenic mechanisms in the Mycoplasma arthritidis polyarthritis of rats. Rheumatol Int 1989; 9: 193-196.

23. Cole BC, Atkin CL. The Mycoplasma arthritidis T-cell mitogen, MAM: a model superantigen. Immunol Today 1991; 12: $271-276$

24. Simecka JW, Davis JK, Davidson MK, Ross SE, Stadtländer CTK-H, Cassell GH. Mycoplasma diseases of animals. In: Maniloff J, McElhaney RN, Finch LR, Baseman JB (eds) Mycoplasmas. Molecular biology and pathogenesis. Washington, DC, American Society for Microbiology, 1992: 391-415.

25. Cole $\mathrm{BC}$, Griffiths MM. Triggering and exacerbation of autoimmune arthritis by the Mycoplasma arthritidis superantigen MAM. Arthritis Rheum 1993; 36: 994-1002. 